\title{
PENGEMBANGAN PERANGKAT KENDALI JARAK JAUH SISTEM PENDINGIN PRIMER REAKTOR KARTINI
}

\section{DEVELOPMENT OF REMOTE-CONTROL DEVICE FOR KARTINI REACTOR PRIMARY COOLING SYSTEM}

\author{
Zulfikar Elran Bhagaskara ${ }^{1}$, Tri Nugroho Hadi Susanto ${ }^{1}$ \\ ${ }^{1}$ Pusat Sains dan Teknologi Akselerator BATAN-Yogyakarta \\ Email: zulfikar.elran@batan.go.id
}

Diterima : 26 Agustus 2020, diperbaiki : 25 September 2020, disetujui : 8 Oktober 2020

\begin{abstract}
ABSTRAK
PENGEMBANGAN PERANGKAT KENDALI JARAK JAUH SISTEM PENDINGIN PRIMER

REAKTOR KARTINI.Telah dibuat perangkat kendali jarak jauh sistem pendingin primer Reaktor Kartini. Perangkat ini dibuat untuk meningkatkan efisiensi waktu dan tenaga operator reaktor yang sebelumnya pengoperasian pompa pendingin primer dilakukan secara manual dengan berjalan dari ruang kendali utama berada di lantai 3 menuju panel kendali yang berada di lantai 1. Perangkat ini dibuat menggunakan komponen utama berupa programmable logic controller Siemens S7-1200. Pembuatan perangkat dilakukan dengan langkah-langkah berupa modifikasi wiring kendali sistem pendingin primer, pembuatan halaman web menggunakan kode Hypertext Markup Language sebagai user interface, seting komunikasi nirkabel antara Programmable Logic Controller dengan komputer di Ruang Kendali Utama menggunakan protokol Transmission Control Protocol/Internet Protocol, dan pengujian perangkat secara keseluruhan. Hasil pengujian menunjukkan bahwa pengembangan perangkat ini tidak mengganggu kinerja kendali lokal dari sistem pendingin primer yang sudah ada. Waktu yang dibutuhkan untuk sekali menghidupkan/mematikan sistem Primer juga berkurang dari rata-rata 1 menit menjadi 2 detik. Pengembangan perangkat ini memberikan kemudahan berupa usaha dan waktu yang digunakan operator untuk menghidupkan/ mematikan sistem primer menjadi lebih ringan dan singkat, dan kendali pengoperasian sistem pendingin primer menjadi terpusat di ruang kendali utama.
\end{abstract}

Kata Kunci: Kendali jarak jauh, sistem pendingin primer, Reaktor Kartini, PLC.

\begin{abstract}
DEVELOPMENT OF REMOTE-CONTROL DEVICE FOR KARTINI REACTOR PRIMARY COOLING SYSTEM. Remote control device for the Kartini Reactor primary cooling system has been made. This device was made to increase efficiency of reactor operator time and energy. Previously the primary coolant pump operation was carried out manually by walking from main control room on 3rd floor to the control panel on 1st floor. This device is made using programmable logic controller Siemens S7-1200 as the main component. This device development is done in several steps, that are modify the primary cooling system control wiring, creating a web page using hypertext markup language code as user interface, setting up wireless communication between the programmable logic controller and the computer in the Main Control Room using the transmission control protocol / internet protocol, and testing the whole device. The test results show that the development of device doesn't disturb the performance of the existing primary cooling system local control. The time taken to turn on / off
\end{abstract}


the Primary system was also reduced from an average of 1 minutes to 2 seconds. The development of this device provides advantages in the form of effort and time that used by the operator to turn on / off the primary cooling system to be easier and shorter, and also control of the primary cooling system become centralized in the main control room.

Keywords: Remote control, primary cooling system, Kartini Reactor, PLC.

\section{PENDAHULUAN}

$R$ eaktor Kartini merupakan reaktor nuklir jenis reaktor riset yang beroperasi pada daya maksimal100kW. Daya yang dibangkitkan Reaktor Kartini berupa panas yang dihasilkan dari reaksi pembelahan bahan bakar nuklir. Dalam operasi reaktor, panas yang dihasilkan Reaktor Kartini tidak dimanfaatkan namun dibuang ke lingkungan menggunakan sistem pendingin primer, penukar panas (heat exchanger) dan sistem pendingin sekunder. Sistem pendingin primer Reaktor Kartini memiliki dua pompa pendingin yang dapat dioperasikan secara bergantian. Masingmasing pompa tersebut terhubung dengan heat exchanger yang berbeda jenis. Pompa pendingin primer 1 terhubung dengan heat exchanger jenis shell and tube, sedangkan pompa pendingin primer 2 terhubung dengan heat exchanger jenis plate. Selain dua pompa tersebut, terdapat juga pompa demin untuk mensirkulasikan air pendingin primer ke dalam perangkat demineralizer. Skema dari sistem pendingin primer Reaktor Kartini ditunjukkan pada Gambar 1 [1].

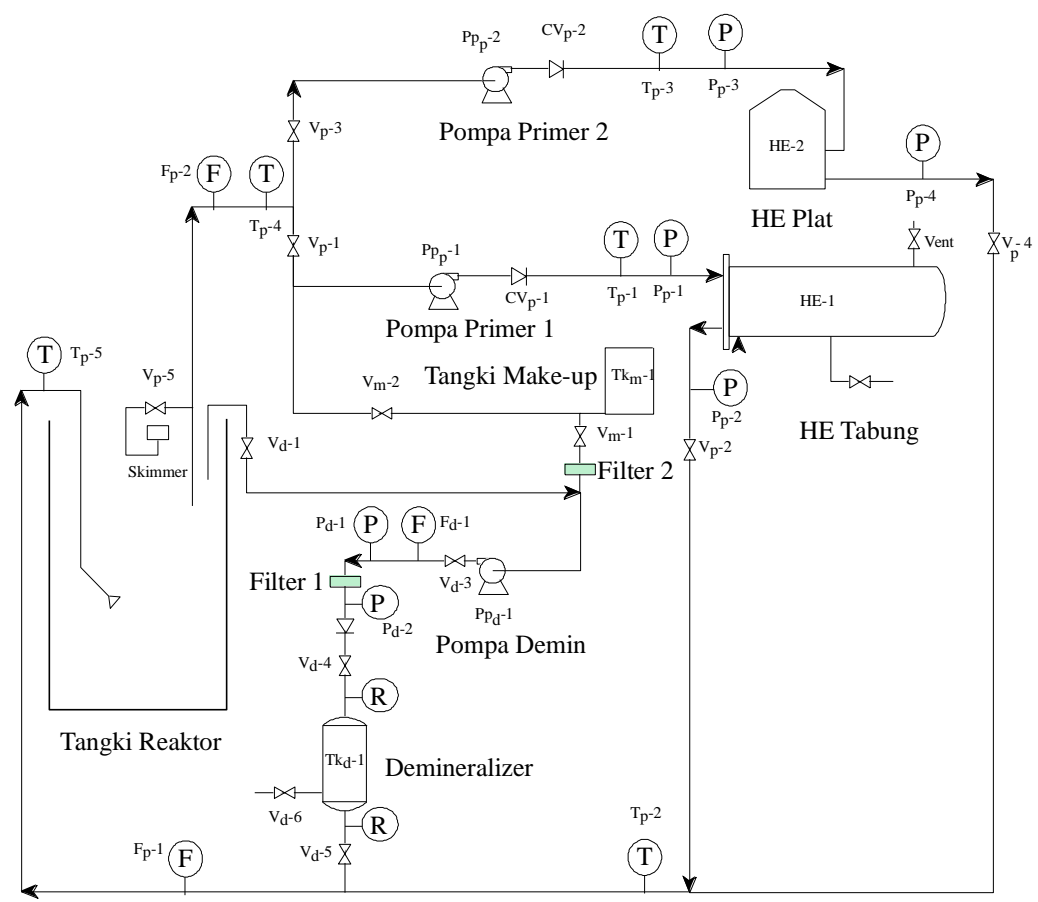

Gambar 1. Skema sitem pendingin primer Reaktor Kartini [1]. 
Sistem pendingin primer terus menerus bekerja sebelum hingga sesudah reaktor beroperasi untuk membuang panas sisa operasi reaktor. Namun pada kondisi tertentu sistem pendingin primer Reaktor Kartini dihidupkan saat start-up reaktor, dimatikan begitu reaktor mencapai daya maksimal, lalu dihidupkan kembali setelah reaktor shutdown. Hal ini biasanya dilakukan pada saat kalibrasi daya reaktor atau penentuan koefisien reaktifitas suhu reaktor [2]. Sebelum adanya perangkat kendali jarak jauh, untuk menghidupkan atau mematikan pompa pendingin primer masih dilakukan secara manual, sehingga operator reaktor harus naik turun tangga dari Ruang Kendali Utama (RKU) di lantai 3 gedung reaktor menuju panel kendali on/off sistem pendingin primer di lantai 1 gedung reaktor. Hal ini kurang efisien terhadap waktu dan tenaga karena dalam sekali percobaan penentuan koefisien reaktifitas suhu, sistem pendingin primer bisa dihidupkan dan dimatikan beberapa kali.

Guna mempermudah operator reaktor dalam mengoperasikan sistem pendingin primer, maka dibuat perangkat kendali jarak jauh untuk sistem pendingin primer. Perangkat kendali jarak jauh ini dibuat menggunakan Programmable Logic Controler (PLC). Operator reaktor dapat mengendalikan pompa pendingin primer dari ruang kendali utama dengan memberi perintah kepada PLC melalui halaman web, lalu PLC akan mengatur on/off pompa primer sesuai perintah dari operator. Perangkat kendali ini juga dibuat agar sistem pendingin primer tetap bisa beroperasi menggunakan panel kendali lokal yang ada saat ini, meskipun PLC mengalami kerusakan.

\section{TINJAUAN PUSTAKA}

\section{Programmable Logic Controller}

Programmable logic controller (PLC) adalah sebuah komputer kelas industri yang dapat diprogram untuk melakukan fungsi kendali. Penggunaan PLC dapat mengurangi banyaknya penggunaan kabel kontrol bila dibandingkan dengan rangkaian kontrol relay konvensional. Keuntungan lainnya adalah pemrograman dan instalasi yang mudah, kecepatan kendali tinggi, kompatibilitas dengan jaringan yang ada, kemudahan dalam troubleshooting, dan kehandalan yang tinggi. [4]

Sebuah PLC dapat dibagi menjadi beberapa bagian, yaitu CPU, input/output, power supply, dan perangkat pemrograman. CPU bertugas mengendalikan semua aktivitas PLC dan dapat diprogram sesuai keinginan pengguna. Program PLC tersebut dijalankan secara berulang yang disebut sebagai scan. Proses scan suatu PLC dimulai dengan CPU membaca status input, kemudian program aplikasi dijalankan, lalu setelah eksekusi program selesai CPU melakukan tugas diagnostik dan komunikasi internal. Selanjutnya, status semua output diperbarui. Proses ini diulang terus menerus selama PLC berada dalam kondisi run [4].

Input suatu PLC dapat berupa hardware di lapangan, atau dapat juga berupa perintah melalui software. Dalam penelitian ini input PLC dibuat melalui 
software web server untuk mengurangi jumlah instalasi peralatan di lapangan.

S7 1200 adalah PLC buatan Siemens yang memiliki desain ringkas dan konfigurasi fleksibel, dimana CPU PLC sudah langsung terintegrasi dengan dengan catu daya, terminal input output, PROFINET dan banyak fungsi lainnya [5]. Penelitian ini menggunakan PLC S7 1200 seri $1214 C$ AC/DC/RLY yang sudah terintegrasi dengan power supply, digital input, digital output relay, analog input, dan port ethernet untuk komunikasi. Adapun bentuk dan spesifikasi dari PLC S7-1200 tersebut disajikan pada Gambar 2 dan Tabel 1.

Tabel 1. Spesifikasi PLC Siemens S7 1200 [5].

\begin{tabular}{cll}
\hline No. & Parameter & \multicolumn{1}{c}{ Keterangan } \\
\hline 1. & Power supply & 220 VAC \\
\hline 2. & Work memory & 75 Kbytes \\
\hline 3. & Load memory & $\begin{array}{l}4 \\
\text { expandable }\end{array}$ \\
\hline 4. & $\begin{array}{l}\text { On-board } \\
\text { digital I/O }\end{array}$ & $\begin{array}{l}\text { 14 input/10 relay } \\
\text { output }\end{array}$ \\
\hline 5. & $\begin{array}{l}\text { On-board } \\
\text { analog I/O }\end{array}$ & $\begin{array}{l}\text { 2 input 0-10V 10 } \\
\text { bit }\end{array}$ \\
\hline
\end{tabular}

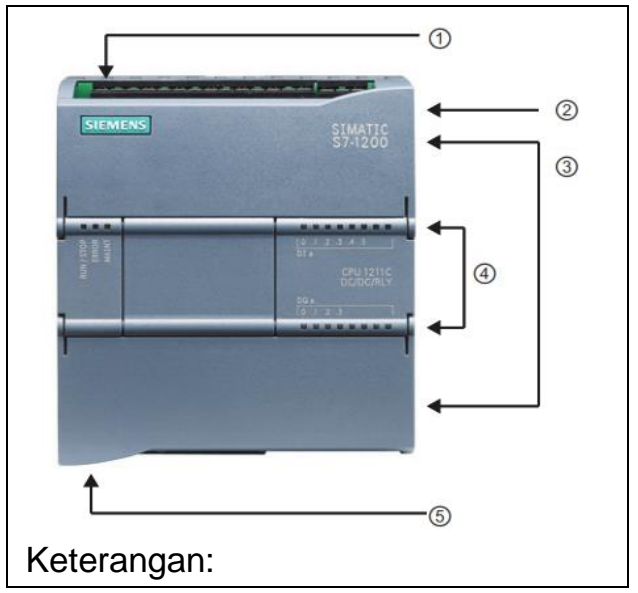
(1) Koneksi catu daya.
(2) Slot kartu memori.
(3) Koneksi I/O.
(4) Lampu indikasi status I/O.
(5) Konektor profinet.

Gambar 2. PLC Siemens S7-1200 [5].

\section{Web Server}

Web server adalah alat yang diberi tugas untuk menerima permintaan dari klien lalu berusaha untuk membalasnya dalam bentuk yang dapat dipahami, biasanya dengan menyajikan halaman web. Adapun yang dimaksud klien adalah perangkat atau program yang mengakses layanan dari server. Komunikasi antara browser dan web server diatur oleh standar komunikasi yang disebut Hyper Text Transfer Protocol atau HTTP. Antara klien dan server bisa terdapat beberapa perangkat, seperti router, proksi, gateway, dan sebagainya. Peralatan tersebut memiliki peran yang berbeda dalam memastikan permintaan dan tanggapan ditransfer dengan benar antara klien dan server [6].

Pada tingkat paling dasar, proses permintaan dan tanggapan antara web browser dengan web server terdiri atas langkah-langkah yang ditunjukkan diagram alir pada Gambar 3 [6]. 


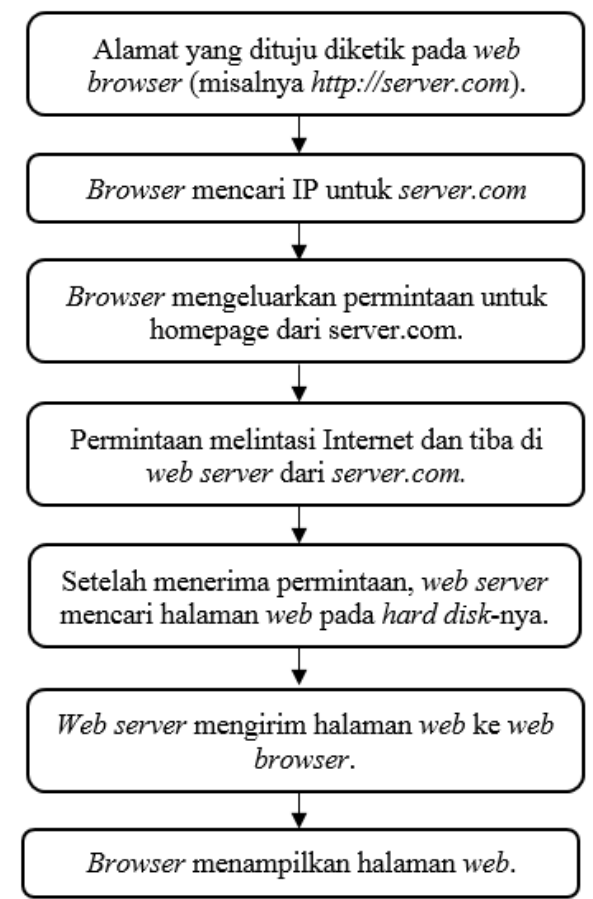

Gambar 3. Diagram alir permintaan dan tanggapan halaman web.

Halaman web sendiri tersusun dari teks-teks yang ditulis dalam format Hypertext Markup Language (HTML). Selain itu banyak halaman web yang perilaku dinamisnya menggunakan kode JavaScript dan kode Cascading Style Sheets (CSS) untuk membentuk presentasi halaman web tersebut [7].

\section{METODOLOGI}

Kegiatan penelitian dilaksanakan dalam beberapa tahap. Tahap pertama adalah modifikasi wiring kendali sistem pendingin primer. Tahap kedua yaitu membuat halaman web untuk mengendalikan PLC. Tahap ketiga yakni menyeting komunikasi antara PLC dengan komputer di Ruang Kendali Utama (RKU). Tahap terakhir adalah menguji coba keseluruhan sistem yang dibuat dengan mengendalikan sistem pendingin primer dari RKU.

\section{Modifikasi Wiring Kendali Sistem Pendingih Primer}

Modifikasi wiring kendali sistem pendingin primer dilakukan dengan cara memasang kontak normally open relay secara paralel dengan tombol start dan kontak normally close relay secara seri dengan tombol stop, kemudian kontrol on/off relay dipicu oleh output PLC. Hal ini berarti diperlukan 2 buah relay untuk mewakili fungsi masing masing tombol start/stop tersebut. Walaupun output PLC sudah berupa relay, namun output PLC tidak langsung dihubungkan dengan kendali start/stop pendingin primer apabila PLC mengalami masalah, sistem pendingin primer tetap bisa dikendalikan menggunakan tombol start/stop yang ada. Modifikasi wiring kendali sistem pendingin primer dapat dilihat pada Gambar 4, dan alokasi penggunaan output PLC dapat dilihat pada Tabel 2. Pada Gambar 4, relay tambahan diberi nama R1 sampai R6 (dilingkari merah). 


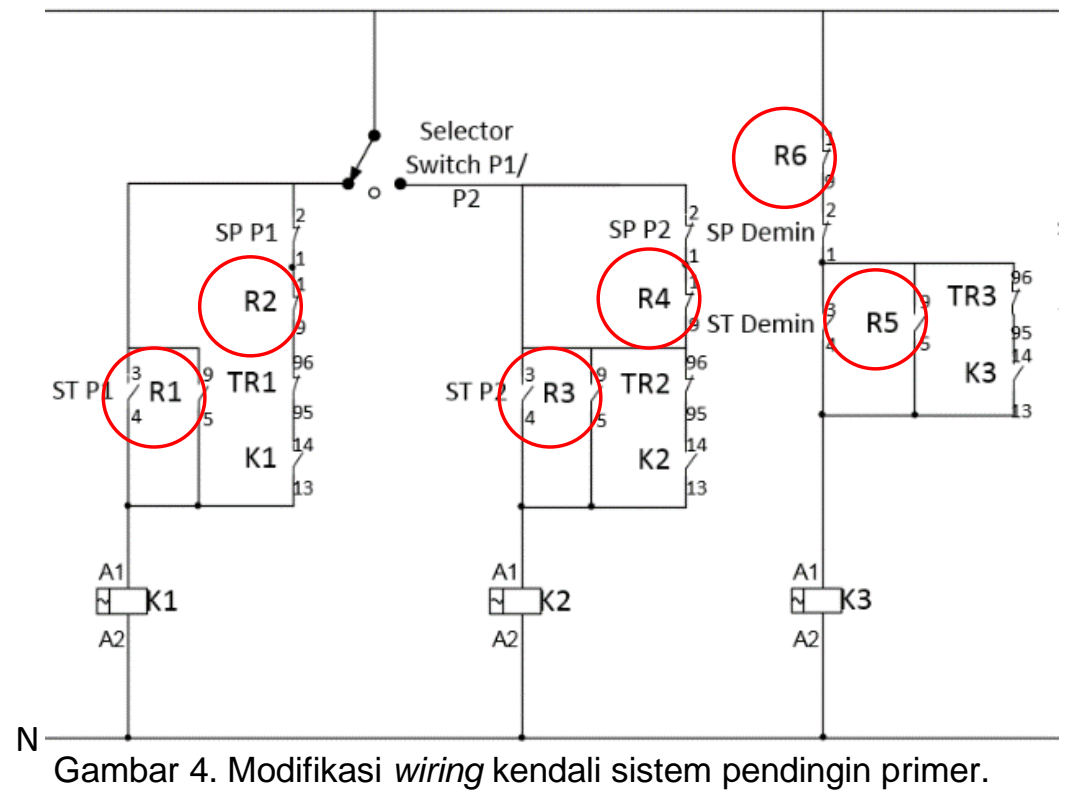

Tabel 2. Alokasi penggunaan output PLC.

\begin{tabular}{ccc}
\hline No. & $\begin{array}{r}\text { Alamat } \\
\text { Output }\end{array}$ & Fungsi \\
\hline 1. & Q0.0 & Start pompa 1. \\
\hline 2. & Q0.1 & Stop pompa 1. \\
\hline 3. & Q0.2 & Start pompa 2. \\
\hline 4. & Q0.3 & Stop pompa 2. \\
\hline 5. & Q0.4 & $\begin{array}{c}\text { Start pompa } \\
\text { demin. }\end{array}$ \\
\hline 6. & Q0.5 & $\begin{array}{c}\text { Stop pompa } \\
\text { demin. }\end{array}$ \\
\hline
\end{tabular}

Masing-masing alamat PLC tersebut akan aktif secara terus menerus bila menerima perintah untuk aktif dari web server. Bila suatu alamat aktif secara terus menerus, maka perintah lain tidak dapat dijalankan untuk mengendalikan sistem pendingin primer. Sehingga perlu diprogram agar hanya aktif 1 sekon saat menerima perintah dari web server.
Contoh program ladder diagram untuk output Q0.0 ditunjukkan pada Gambar 5.

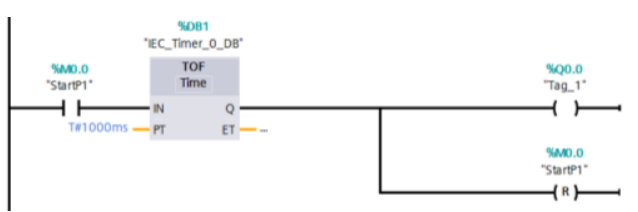

Gambar 5. Program ladder diagram untuk output Q0.0.

\section{Pembuatan Halaman Web}

Halaman web untuk memberi perintah ke PLC dibuat menggunakan format HTML dengan bantuan program Visual Studio Code, kemudian untuk desain halaman web menggunakan framework Bootsrap V4.1.0.

Seluruh variabel dari PLC yang akan diakses oleh halaman web, harus dideklarasikan terlebih dahulu. Contoh deklarasi variabel PLC untuk start/stop pompa 1 ditunjukkan pada Gambar 6. Deklarasi variabel yang ditulis pada kode 
HTML harus sama dengan variabel yang dideklarasikan pada PLC untuk masingmasing alamat input/output.

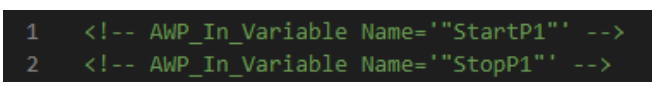

Gambar 6. Deklarasi variabel PLC.

Setelah variabel dideklarasikan, variabel tersebut dapat diakses menggunakan instruksi "submit" dan dituliskan "value" yang diinginkan. Hasil akhir tampilan halaman web untuk kendali sistem pendingin primer ditunjukkan pada Gambar 7. Setelah halaman web selesai dibuat, lalu halaman web diunduh (download) ke dalam memory PLC. Fungsi masing masing tombol perintah pada halaman web adalah mengaktifkan alamat PLC sesuai fungsi yang ditunjukkan pada Tabel 2.

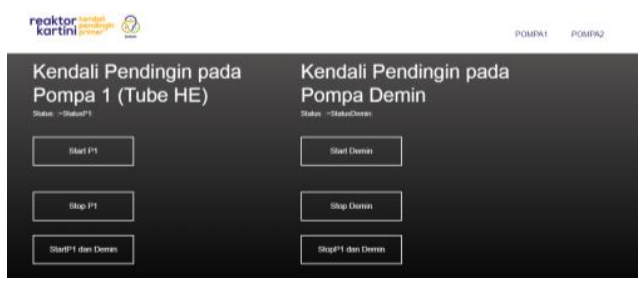

Gambar 7. Tampilan halaman web untuk kendali sistem pendingin primer.

\section{Setting Komunikasi PLC dan Komputer}

Protokol komunikasi yang digunakan antara komputer RKU dengan PLC adalah TCP/IP, adapun media komunikasi yang digunakan berupa wireless access point sehingga tidak perlu menyiapkan kabel ethernet dari RKU ke PLC yang diletakkan di dekat panel pendingin primer. Skema komunikasi antara komputer di RKU dengan PLC ditunjukkan pada Gambar 8.

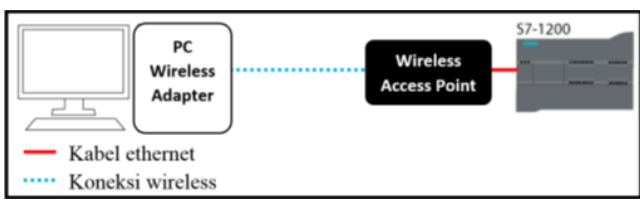

Gambar 8. Skema komunikasi antara komputer di RKU dengan PLC. [8]

\section{Uji Coba Perangkat Kendali Jarak Jauh}

Uji coba perangkat kendali jarak jauh merupakan tahap akhir dari penelitian ini. Tahap ini bertujuan untuk menguji secara keseluruhan perangkat kendali jarak jauh untuk pendingin primer yang telah dibuat. Pengujian dilakukan dengan mencoba apakah masing-masing tombol pada halaman web dapat memberi perintah dengan benar kepada PLC, lalu bila perintah yang diberikan sudah benar diuji juga apakah wiring antara PLC, relay, dan panel kendali sistem pendingin primer sudah benar sehingga dapat memberi perintah on/off pompa dengan benar.

\section{HASIL DAN PEMBAHASAN}

\section{Modifikasi Wiring Kendali Sistem Pendingin Primer \\ Modifikasi wiring kendali sistem} pendingin primer dilakukan dengan menambahkan 6 relay seperti desain pada Gambar 2, dan hasil pemasangan relay tambahan tersebut ditunjukkan pada Gambar 9. Unjuk kerja masingmasing relay ini diuji terlebih dahulu tanpa menggunakan PLC, hal ini dilakukan untuk memastikan wiring 
antara relay dengan panel kendali sistem kendali primer tidak terdapat masalah, dan memastikan bahwa tanpa PLC pun sistem kendali primer tetap dapat berfungsi.

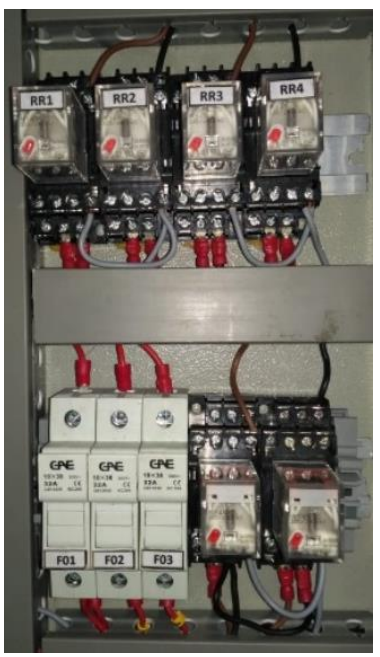

Gambar 9. Relay tambahan untuk kendali jarak jauh sistem pendingin primer.

Pengujian relay dilakukan dengan memberi tegangan 220 VAC pada coil relay, relay yang aktif akan menjalankan fungsi tertentu. Misalnya ketika relay 1 diaktifkan maka pompa 1 akan hidup dan ketika relay 2 diaktifkan maka pompa 1 akan berhenti. Tombol-tombol pada panel kendali sistem pendingin primer juga diuji untuk memastikan bahwa fungsinya tidak terganggu. Modifikasi wiring kendali sistem pendingin primer menunjukkan hasil yang sesuai rancangan, dengan hasil pengujian secara keseluruhan ditunjukkan pada tabel 3 .
Tabel 3. Hasil pengujian modifikasi wiring kendali sistem pendingin primer.

\begin{tabular}{|c|c|c|c|}
\hline No. & Nama Alat & Fungsi & Hasil \\
\hline \multicolumn{4}{|c|}{ Relay tambahan untuk modifikasi wiring } \\
\hline 1. & Relay 1 & $\begin{array}{l}\text { Start } \\
\text { pompa } 1\end{array}$ & $\begin{array}{l}\text { Pompa } \\
1 \text { run }\end{array}$ \\
\hline 2. & Relay 2 & $\begin{array}{l}\text { Stop } \\
\text { pompa } 1\end{array}$ & $\begin{array}{l}\text { Pompa } \\
1 \text { stop }\end{array}$ \\
\hline 3. & Relay 3 & $\begin{array}{l}\text { Start } \\
\text { pompa } 2\end{array}$ & $\begin{array}{l}\text { Pompa } \\
2 \text { run }\end{array}$ \\
\hline 4. & Relay 4 & $\begin{array}{l}\text { Stop } \\
\text { pompa } 2\end{array}$ & $\begin{array}{l}\text { Pompa } \\
2 \text { stop }\end{array}$ \\
\hline 5. & Relay 5 & $\begin{array}{l}\text { Start } \\
\text { pompa } \\
\text { demin }\end{array}$ & $\begin{array}{l}\text { Pompa } \\
\text { demin } \\
\text { run }\end{array}$ \\
\hline 6. & Relay 6 & $\begin{array}{l}\text { Stop } \\
\text { pompa } \\
\text { demin }\end{array}$ & $\begin{array}{l}\text { Pompa } \\
\text { demin } \\
\text { stop }\end{array}$ \\
\hline $\begin{array}{l}\text { Ton } \\
\text { sist }\end{array}$ & $\begin{array}{l}\text { existing } \\
\text { n pendingin }\end{array}$ & $\begin{array}{l}\text { dari panel } \\
\text { imer }\end{array}$ & kendali \\
\hline 7. & $\begin{array}{l}\text { Tombol } \\
\text { start } \\
\text { Pompa } 1\end{array}$ & $\begin{array}{l}\text { Start } \\
\text { pompa } 1\end{array}$ & $\begin{array}{l}\text { Pompa } \\
1 \text { run }\end{array}$ \\
\hline 8. & $\begin{array}{l}\text { Tombol } \\
\text { stop } \\
\text { pompa } 1\end{array}$ & $\begin{array}{l}\text { Stop } \\
\text { pompa } 1\end{array}$ & $\begin{array}{l}\text { Pompa } \\
1 \text { stop }\end{array}$ \\
\hline 9. & $\begin{array}{l}\text { Tombol } \\
\text { start } \\
\text { pompa } 2\end{array}$ & $\begin{array}{l}\text { Start } \\
\text { pompa } 2\end{array}$ & $\begin{array}{l}\text { Pompa } \\
2 \text { run }\end{array}$ \\
\hline 10. & $\begin{array}{l}\text { Tombol } \\
\text { stop } \\
\text { pompa } 2\end{array}$ & $\begin{array}{l}\text { Stop } \\
\text { pompa } 2\end{array}$ & $\begin{array}{l}\text { Pompa } \\
2 \text { stop }\end{array}$ \\
\hline 11. & $\begin{array}{l}\text { Tombol } \\
\text { start } \\
\text { pompa } \\
\text { demin }\end{array}$ & $\begin{array}{l}\text { Start } \\
\text { pompa } \\
\text { demin }\end{array}$ & $\begin{array}{l}\text { Pompa } \\
\text { demin } \\
\text { run }\end{array}$ \\
\hline 12. & $\begin{array}{l}\text { Tombol } \\
\text { stop } \\
\text { pompa } \\
\text { demin }\end{array}$ & $\begin{array}{l}\text { Stop } \\
\text { pompa } \\
\text { demin }\end{array}$ & $\begin{array}{l}\text { Pompa } \\
\text { demin } \\
\text { stop }\end{array}$ \\
\hline
\end{tabular}




\section{Pembuatan Halaman Web dan pengaturan komunikasi}

Agar PLC dan komputer dapat berkomunikasi, maka kedua perangkat tersebut diseting dalam satu subnet. Kemudian guna meningkatkan keamanan maka untuk mengakses PLC dari komputer diberi tiga lapis kontrol akses yaitu wireless network yang di hidden, password untuk login ke wireless adapter, dan password untuk login ke web server PLC. Seting komunikasi berhasil dilakukan dimana PLC dan komputer dapat berkomunikasi.

Halaman web yang telah diunduh ke PLC kemudian coba diakses langsung menggunakan web browser dan menunjukkan tampilan sesuai halaman web yang telah dibuat. Kemudian masing-masing tombol pada halaman web diuji fungsi dan diperoleh hasil seperti ditunjukkan pada Tabel 4. Hasil pengujian tersebut menunjukkan bahwa halaman web yang dibuat sudah mengaktifkan alamat PLC sesuai deklarasi pada Tabel 2.

Tabel 4. Fungsi tombol pada halaman Web.

\begin{tabular}{ccc}
\hline No. & Tombol & Fungsi \\
\hline 1. & Start $\mathrm{P} 1$ & Q0.0 aktif $1 \mathrm{~s}$ \\
\hline 2. & Stop $\mathrm{P} 1$ & Q0.1 aktif $1 \mathrm{~s}$ \\
\hline 3. & Start $\mathrm{P} 2$ & Q0.2 aktif $1 \mathrm{~s}$ \\
\hline
\end{tabular}

\begin{tabular}{ccc}
\hline 4. & Stop P2 & Q0.3 aktif 1s \\
\hline 5. & Start Demin & Q0.4 aktif 1s \\
\hline 6. & Stop Demin & Q0.5 aktif 1s \\
\hline 7. & $\begin{array}{c}\text { Start P1 dan } \\
\text { Demin }\end{array}$ & $\begin{array}{c}\text { Q0.0 dan Q0.4 } \\
\text { aktif 1s }\end{array}$ \\
\hline 8. & Stop P1 dan & Q0.1 dan Q0.5 \\
& Demin & aktif 1s \\
\hline 9. & Start P2 dan & Q0.2 dan Q0.4 \\
& Demin & aktif 1s \\
\hline 10. & Stop P2 dan & Q0.3 dan Q0.5 \\
& Demin & aktif 1s \\
\hline
\end{tabular}

\section{Uji Coba Perangkat Kendali Jarak Jauh}

Setelah seluruh sub bagian diuji dan menunjukkan hasil sesuai rancangan, maka pada tahap terakhir ini perangkat kendali jarak jauh diuji secara keseluruhan. Pengujian dilakukan dengan mengakses halaman web yang telah diunduh ke dalam PLC. Masingmasing tombol pada halaman web diuji dengan menekan tombol tersebut, lalu masing masing tombol harus mengaktifkan alamat PLC sesuai Tabel 4, masing-masing alamat PLC yang aktif akan mengaktifkan relay lalu relay harus menjalankan fungsi seperti pada Tabel 3. Misalnya ketika tombol Start P1 pada halaman web ditekan, maka output Q0.0 pada PLC harus aktif, relay 1 aktif, dan Pompa 1 hidup. Hasil pengujian perangkat kendali jarak jauh secara lengkap dapat dilihat pada Tabel 5 .

Tabel 5. Hasil pengujian sistem kendali jarak jauh.

\begin{tabular}{cccc}
\hline Tombol & PLC & Relay & Fungsi \\
\hline Start P1 & Q0.0 aktif & Relay 1 aktif & Pompa 1 run \\
\hline Stop P1 & Q0.1 aktif & Relay 2 aktif & Pompa 1 stop \\
\hline Start P2 & Q0.2 aktif & Relay 3 aktif & Pompa 2 run \\
\hline
\end{tabular}




\begin{tabular}{cccc}
\hline Stop P2 & Q0.3 aktif & Relay 4 aktif & Pompa 2 stop \\
\hline Start Demin & Q0.4 aktif & Relay 5 aktif & Pompa demin run \\
\hline Stop Demin & Q0.5 aktif & Relay 6 aktif & Pompa demin stop \\
\hline Start P1 \& Demin & Q0.0 \& Q0.4 aktif & Relay 1 \& 5 aktif & Pompa 1 \& demin run \\
\hline Stop P1 \& Demin & Q0.1 \& Q0.5 aktif & Relay 2 \& 6 aktif & Pompa 1 \& demin stop \\
\hline Start P2 \& Demin & Q0.2 \& Q0.4 aktif & Relay 3 \& 5 aktif & Pompa 2 \& demin run \\
\hline Stop P2 \& Demin & Q0.3 \& Q0.5 aktif & Relay 4 \& 6 aktif & Pompa 2 \& demin stop \\
\hline
\end{tabular}

Berdasarkan uji coba pengoperasian perangkat kendali jarak untuk eksperimen kalibrasi daya reaktor menunjukkan bahwa waktu rata-rata yang dibutuhkan oleh operator reaktor untuk menghidupkan atau mematikan sistem pendingin primer adalah 2 detik sedangkan waktu rata-rata yang dibutuhkan sebelum menggunakan perangkat kendali jarak jauh yakni 1 menit [10].

Dengan demikian pembuatan perangkat kendali jarak jauh ini memberikan kemudahan bagi operator dalam mengoperasikan sistem pendingin primer. Kemudahan yang dimaksud yaitu usaha dan waktu yang digunakan operator untuk menghidupkan/ mematikan sistem primer menjadi lebih ringan dan singkat.

\section{KESIMPULAN}

Berdasarkan hasil pembuatan dan pengujian perangkat kendali jarak jauh sistem pendingin primer Reaktor Kartini dapat disimpulkan bahwa:

- Perangkat kendali jarak jauh sistem pendingin primer Reaktor Kartini telah selesai dibuat. Perangkat dibuat mengunakan PLC Siemens S7-1200, yang diakses melalui interface web browser dari komputer di ruang kendali utama Reaktor Kartini secara nirkabel dengan protokol komunikasi TCP/IP.

- Dengan menggunakan perangkat kendali jarak jauh, waktu yang dibutuhkan untuk sekali menghidupkan atau mematikan sistem pendingin primer saat experimen berkurang drastis menjadi rata-rata 2 detik dari awalnya rata-rata 1 menit bila dilakukan secara manual.

- Pengembangan perangkat ini memberikan kemudahan berupa usaha dan waktu yang digunakan operator untuk menghidupkan/ mematikan sistem primer menjadi lebih ringan dan singkat.

- Adanya perangkat ini menjadikan kendali pengoperasian sistem pendingin primer terpusat di RKU.

\section{UCAPAN TERIMA KASIH}

Penulis mengucapkan terima kasih kepada Kepala Pusat Sains dan Teknologi Akselerator dan seluruh staff yang terlibat dalam penyelesaian karya tulis ini.

\section{DAFTAR PUSTAKA}

[1] Badan Tenaga Nuklir Nasional, "Laporan Analisis Keselamatan Reaktor Kartini, Revisi 2 Terbitan 2", Yogyakarta, 2019. 
[2] Badan Tenaga Nuklir Nasional, "Standar Operasional Prosedur Kalibrasi Daya Reaktor No. Dok.: SOP 054.2/RN 00 01/STA 4", Yogyakarta, 2016.

[3] Badan Tenaga Nuklir Nasional, "Log Book Operasi Reaktor Kartini No.53", Yogyakarta, 2020.

[4] F. D. Petruzela, "Programmable Logic Controller", New York: Mc Graw Hill, 2011.

[5] Siemens AG, "Simatic S7-1200 System Manual", Nurnberg, 2012.

[6] R. Nixon, "Learning PHP, MySQL, JavaScript, and CSS, Second Edition", United States of America: O'Reilly Media, 2012.

[7] D. Flanagan, "JavaScript: The Definitive Guide, Sixth Edition", United States of America: O'Reilly Media, 2011.

[8] https://www.fernhillsoftware.com/ help/drivers/siemens-s7/plc-setup- ethernet-s7-1200-1500.html, Diakses Juli 2020.

[9] Siemens AG, "Basic on Creating HTMLs for Simatic CPUs", Germany, 2014.

[10]Badan Tenaga Nuklir Nasional, "Laporan Kegiatan Modifikasi Kendali Sistem Pendingin Primer Reaktor Kartini, Rev 0 Tbt 1, No. Dok.:LKEG 015/RN 00 02/STA 4", Yogyakarta, 2019. 